\title{
The Role of OECD Corporate Governance Principles in the Integration of Commonwealth of Independent States Countries to the World Economy
}

\author{
Prof. Dr. Naim Ata Atabey (Selçuk University, Turkey) \\ Ph.D. Candidate Halenur Yılmaz (Selçuk University, Turkey) \\ Ph.D. Candidate Merve Öz (Selçuk University, Turkey)
}

\begin{abstract}
The founding members of The Organization for Economic Co-operation and Development (OECD) consist of mostly the European countries. The organization which is regional in nature and more focused on Europe has global aims like contributing to developments of world trade and economic development of members and other countries in the process of economic development. Corporate Governance Principles published for the first time in 1999 by OECD that can be adapted by each country according to their circumstances, provide guidance to countries in order to achieve the objectives. Corporate Governance Principles mainly focus on the responsibility, fairness, transparency and accountability. Gaining their independence after the dissolution of Soviet Union, the countries established Commonwealth of Independent States. They began to build their economic structures and make their presence felt in the world economy. Some developments like establishment of capital market can be seen as the best example of that effect. For all countries including Eurasia, adapting to the new institutional arrangements for businesses has become more important to continue their existence. Moreover, such integration between the CIS and world countries will contribute positively to developments of economic and cultural relationships. In this respect, enterprises in CIS countries are expected to shape their organizational structure according to international rules and standards. In this paper, the emerging developments of CIS countries due to being member to OECD and their compliance with Corporate Governance Principles, their possible problems and Corporate Governance Principles which is seen as common ground between CIS and world countries are evaluated.
\end{abstract}

\section{Introduction}

Although the concept of Corporate Governance has been in some studies in the U.S and Japan since $19^{\text {th }}$ century (Morck and Nakamura, 1999) it is seen that it has been widely used in 1980s (Shleifer and Vishny, 1994). In 1990s, this concept has been on the front burner of individual and institutional investors, shareholders, managers and anyone interested in financial market (Gürbüz and Ergincan, 2004).

According to Corporate Governance Committee of Organization for Economic Cooperation and Development (OECD), Corporate Governance is identified in the widest sense as a system in which companies are directed and controlled, and the concept includes a set of series of relationships among the company's management, board of management, shareholders and other interested parties (Gürbüz and Ergincan, 2004). Accordingly, in the framework of corporate governance concept, management problems that arise from separation of ownership and control must be emphasized.

Many studies conducted in the field of corporate governance around the world show that there cannot be single corporate governance model for each country. However, "equality" which refers to all activities of company, shareholders and stakeholders must be treated equally in order to prevent possible conflict of interest; "transparency" which is about -except for information accepted as trade secret and undisclosed to publicdeclaring to the public financial and non-financial information about the company within the timely, accurate, complete, intelligible, interpretable, low-cost and easily accessible manner; "accountability" which states the accountability obligation of board of members against to legal personality of company and also to shareholders and another concept "responsibility" refers to compliance of all activities of company's management on behalf of the joint-stock company to regulations, articles of incorporations and internal regulations and supervision of these. These concepts are considered as generally accepted principles of corporate governance (Dalğar and Pekin, 2011; SPK, 2005). These principles have been the basis reference for national management codes applied in many countries and for international evaluations done for the considered application.

Corporate Governance Principles developed by OECD, have a growing importance, since they form one of the 12 basic international standards in order to robust financial system proposed by Financial Stability Board (FSB) that is strengthened after the crisis owing to its role. Today they are fundamental reference points of international evaluations and applied national governance codes in nearly 100 countries (Şafak, 2012). 


\section{Objective and Historical Developments of OECD}

After World War II, in 1948, Organization for European Economic Cooperation (OEEC) was established in order to carry out Marshall Plan that is prepared for supporting and restructuring Western European Economies, Canada and USA have participated to this organization in order to increase their success and lay out their efforts and workings globally. In 1960 in Paris an agreement for the creation of Organization for Economic Cooperation and Development was signed. As a matter of that agreement, it became effective on 30 September 1960 and OECD was officially founded.

According to $1^{\text {st }}$ article of this agreement, the objectives of OECD has supported following policies:

- To achieve the highest sustainable economic growth and employment and a rising standard of living in Member countries, while maintaining financial stability, and thus to contribute to the development of the world economy;

- To contribute to sound economic expansion in Member as well as non-member countries in the process of economic development; and

- To contribute to the expansion of world trade on a multilateral, non-discriminatory basis in accordance with international obligations.

At the time of the publication of this paper, OECD had 34 members. While the 20 founding members of OECD are the US, Germany, Austria, Belgium, Denmark, France, Netherlands, UK, Ireland, Spain, Sweden, Switzerland, Italy, Iceland, Canada, Luxembourg, Norway, Portugal, Turkey and Greece, later on Australia, Czech Republic, Finland, South Korea, Israel, Japan, Hungary, Mexico, Poland, Slovakia, Chile and New Zealand have become members of this organization. After the collapse of Soviet Union, in the early years of 1990s, in order to accelerate the integration process to the West, Poland, Hungary, Czech Republic and Slovakia have been accepted as members to the organization. Estonia, Israel, Slovenia and Chile joined the organization in 2010 and the accession negotiations are underway with Russia. The European Union Commission also participates the meeting without the right to vote. Brazil, China, Indonesia, South Africa and India have been invited to join the workings of the organization and to accept the organization's principles and applications.

The objectives of OECD in order to solve global economic, social, and management problems and to take the advantages of the opportunities of that process and working together with these 34 countries having democratic structure and market economy are:

- Fighting poverty and gaining wealth in cooperation with economic growth, financial stability, trade, investment, technology, innovation, and entrepreneurship and development fields.

- Ensuring the balance between protecting environment and economic and social development.

- Creating job opportunities and managing effectively and efficiently in the context of social equality.

- Giving recommendations to governments and helping them about understanding new developments and problems and providing solutions to these (MFA, 2014).

\section{OECD Corporate Governance Principles}

Corporate Governance Principles prepared and published by OECD with the help of relevant international institutions and private sector in 1999 includes some guiding principles and a set of standards. Principles are non-binding and they work as a guide for governments and companies to reexamine their understanding of management and to implement the predetermined standards. Changing conditions require making some amendments mandatory. Developments in the fields of social, economic fields necessitated the renewal of corporate governance principles and in 2004 these principles were revised.

In 2013, in order to revise principles that become global and adopted by FSB, all members of FSB have been invited as having equal rights in decision making with the members of OECD. To revise these principles, governing body benefited from business sector, investors, national and international professional organizations, trade unions, civil society organizations and international standard setting organizations and negotiations of shareholders (OECD, 2014).

Corporate governance definition of OECD summarizes the focal point, objectives and content of principles. According to OECD, corporate governance includes the relationship between company's management, board of directors, shareholders and stakeholders. Corporate governance also reveals the company's goal and determines the tools to achieve these goals and ensures how the performance will be monitored. The presence of effective corporate governance helps providing needed confidence to function properly in the market economy, for the whole economy and for each company that has a function in it. As a result, it is estimated that capital cost is reduced and companies are run by using their resources more effectively, so that the growth is supported.

The organization when its origin, founders and current members are taken into consideration, seems as regional, focused on Europe, but with its mission and goals contribute to world economy, works together with the countries whose share on the world economy is rapidly increasing like Brazil, China, India, Indonesia, South 
Africa and Russia concentrate on regional programs including Middle East, North Africa and Eurasia (Şafak, 2012).

\section{CIS Countries in the Eurasian Region}

While the Eurasia is a region, which covers continents of Europe and Asia, as of 2012 there are 93 independent countries in Eurasia. With the decision of dispersion of Soviet Union in 1991, the countries, Russia, Belarus and Ukraine within the Eurasia Project of OECD and then with the participation of other Soviet Countries, Commonwealth of Independent States (CIS) was established. CIS, which is more of a political organization in nature, did not handle economic cooperation well enough between the given countries (Pirimbayev and Ganiyev, 2010).

During the Soviet period because of interdependence between Union of Soviet Socialist Republics (USSR), the economic relations were very close between these countries but in 1991 with the decision of a sudden collapse of USSR, continuing these relations have become impossible because of political and economic (high inflation) reasons and in the first period of independence, the countries have experienced a rapid decline in the production rate. Although the economic relations between these countries have weakened significantly, due to geographical and historical reasons economic cooperation will provide benefit for all countries and it has become mandatory for these countries (Pirimbayev and Ganiyev, 2010).

In that respect, it was felt that an effective economic cooperation organization was vital, and in 2001 Eurasian Economic Community (EurAsEC), which covers the countries like Russia, Belarus, Kazakhstan, Kyrgyzstan and Tajikistan was established. In 2006, Uzbekistan joined the community, but in 2008 mostly for political reasons it was separated. Moldova, Ukraine and Armenia had an observer status in the community. On 18 November 2011, according to agreement signed by Belarus, Russia and Kazakhstan, it was claimed that EurAsEc would be converted to the Eurasian Union in 2015.

\section{Corporate Governance Issues in CIS Countries}

The concept of globalization stated as historical process refers to increasing unification of the entire world economies particularly in the areas of financial markets and trade. According to some approaches, the concept of globalization is expressed as a process of labor and information flow in international area (Dikkaya and Özyakışır, 2008).

Today globalization is an inevitable fact and the necessity of going beyond individual and regional aims for countries is another fact. Therefore, it is expected from CIS countries not to remain outside of these developments and they should tend to be directed to new order which is created all around the world and to adapt to internationally accepted rules and standards. However, when the current states, their characteristics and conditions are considered in detail, it is seen that adopting such adjustments will not be easy.

Regarding CIS countries' macroeconomic indicators, it can be said that they are almost among the least developed countries in the world economy and face similar main economic and financial problems. These core issues are (Bati, 2005; Şafak, 2012):

- Capital markets to which institutional investors have limited contribution, international investments are not enough and there is liquidity shortage.

- Inadequate and underdeveloped capital authorities, stock exchanges, settlement and custody services and other capital market institutions.

- Unfair treatment and weakness about the protection of shareholders' rights and legal regulations.

- The presences of few large companies and shareholders have the largest shares.

- Inadequate principles for the protection of minority rights and setting their rights aside.

- Unaudited accounting records, lack of financial information and mostly absence financial information.

- Existence of economic environment to which investors and shareholders cannot properly reach, inability to access to necessary information that is risky and prevailing uncertainty and non-transparency.

Campos and Kinoshita have found in their study which was conducted on 25 countries in East, Central Europe and the Former Soviet Union in between 1990-1998, Foreign Direct Investments has a positive impact on economic growth (Campos and Kinoshita, 2002).

In 2001 in the Black's study which was applied on 21 Russia's firms, even in the environment in which laws are underdeveloped, an effective corporate governance system in firms will affect these firms' market value in highly positive way (Black, 2001).

Also Sprenger (2002) analyzed Russia enterprises and stated that there is a positive relationship between well performed corporate governance principles and the development of firms' performance (Sprenger, 2002).

After the war with the efforts to build their national economies within the effect of economic crisis Eurasia economies created capital authorities, stock exchanges, settlement and custody services and other capital market 
institutions with the help of international financial institutions. In some countries regulatory authorities and stock exchanges are also have been established. However, as defined these formations are not enough and also undeveloped. The contribution of institutional investors is very limited; lack of international investment and lack of liquidity in the markets shows underdevelopment (Şafak, 2012). Early in this process, to support and strengthening these formations will be possible with corporate governance principles.

The biggest problem which can be overcome with effective corporate governance in CIS economies is because of highly extreme existing lack of trust. An investor has decided to invest to a company or a country will need to trust. Thus, the issue in CIS economies having lack of trust is not about protecting investors, it is about taking the investors in these countries or companies (Bati, 2005).

With the concept of transparency except for trade secrets and undeclared information to the public, timely, accurate, complete, understandable, interpretable, low-cost and easily accessible financial and non financial information related to company will be declared to public. In line with the principles with laws, the investor will feel safe against wrongful acts and will increase the rate of investments given countries.

If only those main problems of CIS countries related to corporate governance are overcome, most probably they can provide largest contribution. In the environment of trust, which can be ensured by adapting these principles and implementing necessary legal regulations, investments will increase and integration to the world will be accelerated in every field and resources in the region will be used most efficiently (Bati, 2005).

\section{Conclusion}

Eliminating all the problems in CIS countries with the regulations by adapting OECD Corporate Governance Principles should not be expected in the short term, since the process of perceiving and adopting the regulations by society and business environment can be done in a long period with educational activities and applications. Of course, that process requires patience and persistence. However, efforts for implementing corporate governance principles will ensure better functioning markets and help creating a culture that provides a set of certain values in terms of ethical behavior (Bati, 2005).

As a result, granting attached importance to corporate governance principles by considering the characteristics of CIS countries:

- $\quad$ Better quality and reliable capital markets will be created.

- Shareholders' rights will be protected.

- Minorities will have shares by protecting their rights.

- Environment of trust will be ensured for investors.

With all of these developments both firms' performances will increase and foreign investment will increase in CIS countries, thus economic development of these countries will increase.

Therefore, OECD corporate governance principles will undertake a duty as a bridge between CIS countries and other countries. And there is no doubt that in the adaptation process to global economy these principles will be a common denominator for both parties, so much so that the denominator will not only increase trade volume and capital amount of CIS countries, but also will change the economic and the social life in those communities in a positive way.

\section{References}

- Bati, 2005. "Eurasia: Corporate Governance Challenges of Non-Listed Companies", OECD Corporate Governance of Non-Listed Companies, p. 163-165.

- Black, 2001. "The Corporate Governance Behavior and Market Value of Russian Firms”, Emerging Markets Review 2, p. 89-108.

- Campos and Kinoshita, 2002, "Foreign Direct Investment as Technology Transferred: Some Panel Evidence from the Transition Economies", William Davidson Working Paper, 438.

- Dalğar and Pekin, 2011. "Kurumsal Yönetim ile Finansal Tablo Manipülasyonu Arasındaki İlişki: İMKB Kurumsal Yönetim Endeksi’nde Yer Alan Şirketlerde Bir Araştırma", Mali Çözüm Dergisi, SeptemberOctober 2011, p.19-43.

- Dikkaya and Özyakışır, 2008. Küreselleşmenin Ekonomi-Politiği. Gazi Kitabevi, Ankara.

- Gürbüz and Ergincan, 2004. Kurumsal Yönetim, Türkiye’deki Durumu ve Geliştirilmesine Yönelik Öneriler. Literatür Yayıncılık, İstanbul.

- MFA, 2014. Repuclic of Turkey, Ministry of Foreign Affairs, http://www.mfa.gov.tr/iktisadi-isbirligi_vegelisme-teskilati-_oecd_.tr.mfa

- Morck and Nakamura, 1999. Japanese Corporate Governance and Macroeconomic Problems. Harvard University. 
- OECD, 2014. 2014 Review of the OECD Principles of Corporate Governance, http://www.oecd.org/daf/ca/2014-review-oecd-corporate-governance-principles.htm

- Pirimbayev and Ganiyev, 2010. “Avrasya Ekonomik Topluluğu: Bir İktisadi İşbirliği Alternatifi”, International Conference on Eurasian Economies, p. 82-85

- Shleifer and Vishny, 1994, "Survey on Corporate Governance", National Bureau of Economic Research Working Paper, 5554.

- SPK, 2005. Kurumsal Yönetim İlkeleri. SPK Yayınları, Ankara.

- Sprenger, 2002. "Ownership and Corporate Governance in Russian Industry: A survey", http://www.ebrd.com/downloads/research/economics/workingpapers/wp0070.pdf

- Şafak, 2012. “Kurumsal Yönetim’de OECD Gündemi ve Bölgesel İşbirliği Çalışmaları”, TKYD Kurumsal Yönetim Dergisi, 15, p.20-23. 